\title{
Study On the Use of Oxidant Scrubbers for Elimination of Interferences Due to Nitrogen Dioxide in Analysis of Atmospheric Dimethylsulfide
}

\author{
Beatriz A. Rodrigues, Luís R.M. Pitombo, Arnaldo A. Cardoso* \\ Departamento de Química Analítica, Universidade Estadual Paulista, CP 355, 14800-900, Araraquara - SP, Brazil
}

\begin{abstract}
Neste trabalho foi avaliado o desempenho de filtros para dióxido de nitrogênio, buscando evitar perdas durante a amostragem de sulfetos orgânicos, provocadas por oxidantes atmosféricos. Diferentes compostos e misturas foram usadas para recobrir superfícies sólidas empregadas na preparação destes filtros. Um sistema automatizado de análise em fluxo foi utilizado para comparar a eficiência de retenção de dióxido de nitrogênio pelos filtros. Entre os materiais testados na preparação dos filtros, as melhores escolhas foram papel ou lã de vidro impregnados com a mistura de sulfato de ferro (II), ácido sulfúrico e ácido pirogalico e ainda os filtros feitos de papel impregnados com trietanolamina. Os resultados obtidos em laboratório com mistura de gás padrão de dimetilsulfeto e experimentos em campo confirmaram a qualidade dos filtros e indicaram que eles podem ser utilizados para evitar a oxidação de sulfetos orgânicos durante a sua amostragem.
\end{abstract}

In this work, oxidant scrubbers were evaluated for their ability to prevent sampling losses of dimethylsulfide caused by reactions with nitrogen dioxide. Various compounds and mixtures were used in the preparation of the oxidant scrubbers. An automatic flow analysis device was used to compare scrubbing efficiency for nitrogen dioxide. Among the scrubbers tested, the best were shown to be the one made with filter paper or glass wool coated with iron (II) sulfate, sulfuric acid and pyrogallic acid, and the one made from with paper coated with triethanolamine. The results obtained under laboratory conditions, using dimethylsulfide standard gas, and in field experiments confirmed that these scrubbers are suitable for the prevention of oxidation during sampling.

Keywords: dimethylsulfide, atmospheric trace gases, sampling technique, nitrogen dioxide scavenger.

\section{Introduction}

Sulfur gases and their reaction products play an important role in the chemistry of the global troposphere and in the biogeochemical sulfur cycle ${ }^{1-5}$. Sulfur compounds are released into the atmosphere by various natural and anthropogenic sources. A substantial increase in anthropogenic sulfur emission has taken place in the last century. It is responsible for malodorous odor in sewage systems, in pulp and paper industry 6-8. In petrochemical processes sulfur compounds can be emitted and cause air pollution during oil prospecting, refining and when fuel is burned $7,9,10$. A few decades ago, biogenic $\mathrm{H}_{2} \mathrm{~S}$ was believed to be the dominant form in which gaseous sulfur was released to the atmosphere. The importance of $\mathrm{H}_{2} \mathrm{~S}$ emission has been continually revised ever since 3-5,11. Current thought attributes an increasing role to dimethylsulfide $\left(\mathrm{CH}_{3}\right)_{2} \mathrm{~S}$ (DMS).

Although knowledge of the chemistry of sulfur compounds in the environment has much improved, there is evidence to suggest that determination of reduced sulfur compounds may often be subject to significant inaccura$\operatorname{cies}^{11}$. The main source of uncertainty associated with these data occurs during the collection step. Frequently, the analysis of these compounds requires a cryogenic preconcentration step to enhance low atmospheric concentrations. The cotrapping of water has been a complex problem: the ice may limit sample volumes and water may be injected into columns $^{12}$. However, the main problem is the destruction of sulfur compounds by oxidizing species $11-15$. The species commonly present in the atmosphere, which may cause sampling losses, include ozone $\left(\mathrm{O}_{3}\right)$, nitrogen dioxide $\left(\mathrm{NO}_{2}\right)$ and hydrogen peroxide $\left(\mathrm{H}_{2} \mathrm{O}_{2}\right)$.

Several types of oxidant scrubbers have been suggested to remove oxidants during cryogenic preconcentration. Braman and co-workers 16 used glass pearl coated with $\mathrm{Na}_{2} \mathrm{CO}_{3}$, Barnard co-workers 17 and Andreae and Raemdonck 18 used packed tubes containing $\mathrm{Na}_{2} \mathrm{CO}_{3} /$ chromasorb as sulfur dioxide scrubbers, Bates and 
Johnson ${ }^{19}$ used glass fiber filters coated with $\mathrm{NaOH}$. A $\mathrm{KOH}$ filter scrubber presented rapid loss of efficiency compared to carbonate-based Anakrom scrubbers ${ }^{20}$. Hofmann co-workers 12 used a Nafion drier in combination with cotton wadding as an oxidant scavenger. Davison and Allen 13 investigated in-line scrubbers utilizing $\mathrm{Na}_{2} \mathrm{CO}_{3}$, $\mathrm{FeSO}_{4} .7 \mathrm{H}_{2} \mathrm{O}$, KI or $\mathrm{KBr}$, either pure or coated onto a chromatographic support, which they found to be ineffective for oxidant removal in moderately polluted air. The KI scrubbers were, however, effective when used in clean remote marine air. Comparing the various oxidant scrubbers, Kittler co-workers ${ }^{14}$ found the $\mathrm{KI} / \mathrm{glycerol} / \mathrm{Vitrex}$ filter to be superior to the scrubbers using $\mathrm{KOH}, \mathrm{NaOH}, \mathrm{MnO}_{2}$ and $\mathrm{Na}_{2} \mathrm{CO}_{3}$. Other methods have included neutral aqueous potassium iodide $^{21}$, ferrous sulfate 22 and $100 \%$ cotton wadding in combination with a Nafion drier ${ }^{23}$. Although much work has been done on the analysis of organic sulfides, the nature of the oxidant interference remains largely unknown. The development and use of new scrubbers is an empirical process $^{11}$. So far there is no consensus about the use of oxidant scrubbers in the analysis of reduced sulfides.

The present work describes the development of oxidant scrubbers for organic sulfide analysis in air. The oxidant scrubbers were made out of solid supports coated with reactive species, to remove the oxidants before the collection of organic sulfide. Comparative data on the scrubbers was obtained by automated flow analysis. Dimethylsulfide, the commonest organic sulfide found in the air, and nitrogen dioxide, the most common oxidant found in the air, were used in the development of this work.

\section{Experimental}

\section{Method of sampling and analysis of organic sulfides}

The method used to sample and analyze organic sulfides is non-cryogenic and has already been reported 24,25 . Glass wool coated with sodium tetrachloropalladate (II) was shown to be very efficient for the collection of dimethylsulfide (DMS). The resulting complex $\left(\left[\mathrm{Pd}(\mathrm{DMS})_{2} \mathrm{Cl}_{2}\right]\right)$ is only slightly soluble in water, but readily soluble in organic solvents. The solutions showed a well-defined absorption peak in the near UV region ( $\mathrm{e}=17.05 \times 10^{3} 1 \mathrm{~mol}^{-1} \mathrm{~cm}^{-1}$ at $303 \mathrm{~nm}$ ) and the absorbance values were proportional to the amount of DMS present. Gases such as $\mathrm{H}_{2} \mathrm{~S}, \mathrm{CO}, \mathrm{CS}_{2}, \mathrm{COS}, \mathrm{NH}_{3}$ and $\mathrm{SO}_{2}$ did not cause interference because they neither react with sodium tetrachloropalladate (II) nor produce compounds soluble in the solvents used to extract the $\left[\mathrm{Pd}(\mathrm{DMS})_{2} \mathrm{Cl}_{2}\right]_{(\mathrm{s})}$. Oxidants such as nitrogen dioxide react with complexed DMS, interfering in subsequent DMS estimation.

The sodium tetrachloropalladate (II) solution was prepared by dissolving $0.6 \mathrm{mmol} \mathrm{PdCl}_{2}$ and $5.1 \mathrm{mmol} \mathrm{NaCl}$ in $55 \mathrm{~mL}$ of $0.1 \mathrm{~mol} \mathrm{~L}$ hydrochloric acid. This solution was used to coat $1.0 \mathrm{~g}$ of glass wool. The coating procedure was that recommended in the previous paper 24 .

Sampling and analysis followed the protocol: a) a sorbent tube containing substarte was connected to the stream of the DMS gas mixture; $b$ ) after collection of DMS, the packing substrate was transferred to an extraction tube; c) the contents of the extraction tube were shaken with toluene until dissolution of $\left[\mathrm{Pd}(\mathrm{DMS})_{2} \mathrm{Cl}_{2}\right]$ was complete; $\left.d\right)$ the solution was transferred to a $5.0 \mathrm{~mL}$ volumetric flask and the volume was adjusted; e) a photometric measurement was made at 303 nm with a Varian-Cary 219 spectrophotometer, using quartz cuvettes of $10.0 \mathrm{~mm}$ optical path length.

\section{Gas generation}

The experimental arrangement is shown in Figure 1. The pumped air was purified in a column containing, in sequence, silica gel, soda lime and activated carbon. The air stream was maintained at a steady temperature by a coil and flowed into a glass chamber containing a permeation tube. The air flow was controlled at $430 \mathrm{~mL} \mathrm{~min}^{-1}$ using a critical orifice. For the DMS standard gas mixture, a permeation tube emitting $519 \mathrm{ngDMS} \mathrm{min}^{-1}$ at $30^{\circ} \mathrm{C}$ (VICI Metronics, Santa Clara, CA) was used. For the $\mathrm{NO}_{2}$ standard gas mixture, the permeation tube described by Teckentrup and Klockow 26 , filled with condensed $\mathrm{NO}_{2}$ gas was used. The permeation rate of $\mathrm{NO}_{2}$ was evaluated by the oxidation of an iodine solution, according to the procedure described by Littman and Benoliel 27 . The permeation rate measured was $1.2 \mu \mathrm{g} \mathrm{NO} \mathrm{Nin}^{-1}$ at $27^{\circ} \mathrm{C}$.

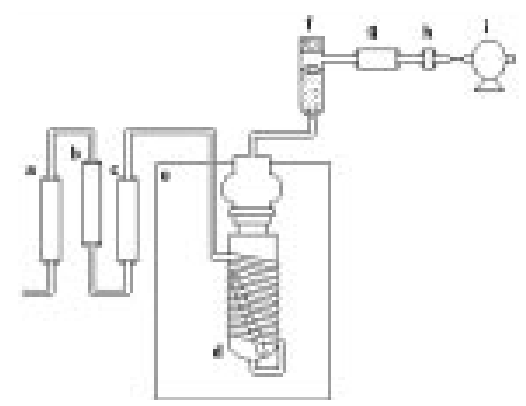

Figure 1. Schematic diagram of apparatus used to produce the gas mixture. a) silica gel; b) soda lime; c) activated carbon; d) permeation tube; e) thermostat bath; f) $\mathrm{NO}_{2}$ scrubber; g) sorbent tube $\left(\mathrm{Na}_{2} \mathrm{PdCl}_{4}\right)$; h) critical orifice; i) air pump.

\section{Oxidant scrubber materials}

Initially, solid substrates were prepared coated with substances known to react with nitrogen dioxide. Glycerol was used in some cases because of its humectant property, 
which should enhance the reactions with nitrogen dioxide. At first, 24 different compositions were tested. The supporting material was prepared from Whatman qualitative filter paper cut into small discs of $5 \mathrm{~mm}$ diameter. The filter paper was soaked in solution, using $50 \mathrm{~mL}$ of aqueous solution per $2.5 \mathrm{~g}$. of filter paper. The filters were dried at $60^{\circ} \mathrm{C}$ in an stove with air circulation, producing the oxidant scrubber materials, which were stored in a desiccator in the dark.

\section{Use of packed scrubbers}

A glass tube with flow connections as in Figure 2 (1.5 $\mathrm{cm}$ internal diameter, $10 \mathrm{~cm}$ length) was filled with $3 \mathrm{~g}$ impregnated filter discs and closed with a Teflon stopper. The scrubber discs were retained in the tube with silanized wool glass. Kittler and co-workers ${ }^{14}$ proposed visual indication of the oxidation of iodide solution to measure the capacity of substrates for retention of oxidant. The blue/purple coloration of a starch-based iodine indicator was used to compare of several scrubbing systems. This visual comparison of the filters showed a discrepancy of up $24 \%$ among replicates. With the purpose of improving this evaluation standard, the measurement of the iodine formed by oxidation was adapted for automated flow analysis (Figure 3). The solution was prepared as suggested by Littman and Benoliel 27 and contained about $200 \mathrm{~g}$ potassium iodide, $36 \mathrm{~g}$ disodium phosphate dodecahydrate, and $14 \mathrm{~g}$ potassium dihydrogen phosphate per liter of solution. The solution of iodine in $20 \%$ potassium iodide and starch exhibits a blue color with a characteristic absorption spectrum and an intense maximum at $477 \mathrm{~nm}$. In this procedure, the scrubber was connected to the stream of air containing nitrogen dioxide. The air, after passing through the scrubber, readily oxidized the iodide to iodine by any nitrogen dioxide remaining. The absorbance of the iodine solution was continuously measured and recorded. The fast formation of iodine was a signal of scrubber breakthrough.

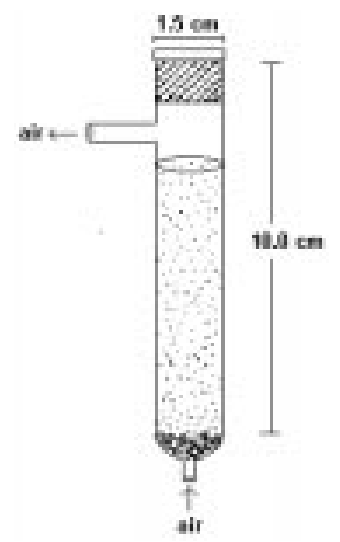

Figure 2. Construction of glass scrubber tube.

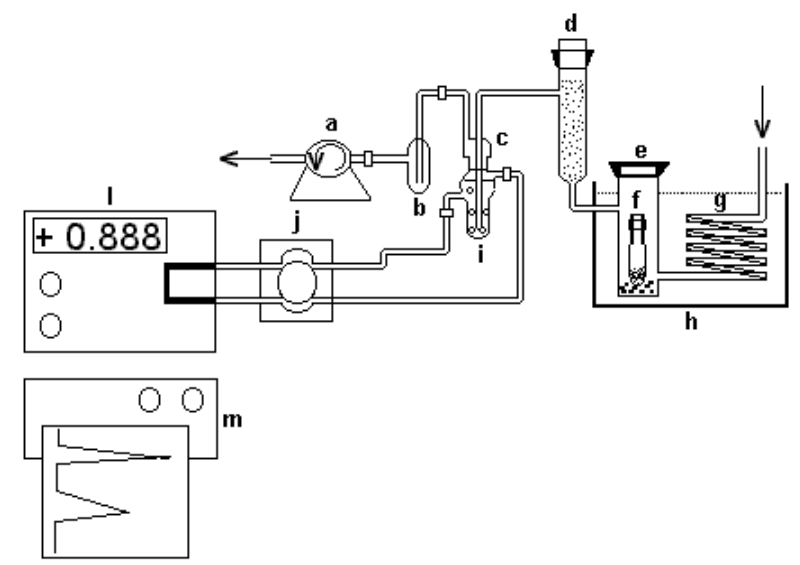

Figure 3. Schematic diagram of automated flow analysis for the measurement of iodine formation. a) air pump; b) security flask; c) bubble flask; d) $\mathrm{NO}_{2}$ scrubber; e) permeation chamber; f) permeation tube; g) coil of glass; h) thermostat bath; i) iodide solution; j) peristaltic pump; 1) spectrophotometer; m) chart recorder.

\section{Results and Discussion}

\section{Interference of nitrogen dioxide}

The reaction of nitrogen dioxide with the dimethylsulfide collected as $\left[\mathrm{Pd}(\mathrm{DMS})_{2} \mathrm{Cl}_{2}\right]_{(\mathrm{s})}$ was evaluated. The procedure involved two steps: first the $\mathrm{Na}_{2} \mathrm{PdCl}_{4(\mathrm{~s})}$ sorbent tube was connected up to the stream of DMS gas mixture standard for $30 \mathrm{~min}$; in the second step, air containing nitrogen dioxide was passed through the sorbent tube in different periods of time. The absorption spectra of the products formed are shown in Figure 4. The absorption spectra of compounds formed by reaction of nitrogen dioxide with the $\left[\mathrm{Pd}(\mathrm{DMS})_{2} \mathrm{Cl}_{2}\right]_{(\mathrm{s})}$ showed the transformation of this compound.



Figure 4. Absorption spectra of compounds formed from the reaction of nitrogen dioxide and $\left[\mathrm{Pd}(\mathrm{DMS})_{2} \mathrm{Cl}_{2}\right]$. The time that the air $/ \mathrm{NO}_{2}$ passed through the sorbent tube was: $\mathrm{t}=0 \min (\mathrm{A}) ; \mathrm{t}=30$ $\min (\mathrm{B})$ and, $\mathrm{t}=6 \mathrm{~h}(\mathrm{C})$.

\section{Efficiency of oxidant scrubbers}

In air sampling, suitable flow rate and duration of sampling 
are two parameters which must be determined for a specific analytical method applied to the compound of interest. If, as here, a sampling time of $30 \mathrm{~min}$ at flow rate $430 \mathrm{~mL} \mathrm{~min}^{-1}$ is chosen for organic sulfide in air, then the oxidant scrubber should remain effective during this period. As a parameter for evaluating the efficiency of oxidant scrubbers for 30 min of sampling, the capacity of a mixture of $\mathrm{NO}_{2}$ and air to oxidize the iodide was first measured. When the air containing nitrogen dioxide was passed directly through the iodide solution at $430 \mathrm{ml} \mathrm{min}^{-1}$, the absorbance of the solution increased linearly (Figure 5), and after $30 \mathrm{~min}$, the signal measured was 0.330 (absorbance units), corresponding to the iodine formed by reaction of $36 \mu \mathrm{g}$ of $\mathrm{NO}_{2}$. In sequence, each one of the scrubbers was connected to the system upstream of the iodide solution and the absorbance of the solution measured. The oxidation of iodide depended on the quantity of $\mathrm{NO}_{2}$ not retained by the scrubber. To evaluate the efficiency of each oxidant scrubber with respect to retention of $\mathrm{NO}_{2}$ during a 30 min sampling interval, the following equation was used:

$\mathrm{e}=\frac{\left(0.330-\mathrm{A}_{30}\right)}{0.330} \times 100$

where $\mathrm{e}$ is the efficiency in percentage of an oxidant scrubber in retention of $\mathrm{NO}_{2}$ after $30 \mathrm{~min} ; 0.330$ is the absorbance of the iodide solution after containing nitrogen dioxide was passed through the solution for $30 \mathrm{~min}$; and $\mathrm{A}_{30}$ is the absorbance of the iodide solution after scrubbed air contained nitrogen dioxide had been passed through the solution for $30 \mathrm{~min}$. Table 1 lists scrubber performance for the 24 different compositions of coating solution studied. The results showed a discrepancy of up to $5 \%$ among replicates.



Figure 5. Absorbance of iodine formed. Air with $\mathrm{NO}_{2}\left(36 \mu \mathrm{g} \mathrm{mL}^{-1}\right)$ was scrubbed and passed through iodide solution; The oxidant scrubbers used were made with the following coating solutions: a) $\left.10 \%(\mathrm{~m} / \mathrm{v}) \mathrm{K}_{2} \mathrm{CO}_{3} ; \mathrm{b}\right) 5 \%(\mathrm{~m} / \mathrm{v}) \mathrm{KI}+5 \%(\mathrm{v} / \mathrm{V})$ glycerol $\left.(\mathrm{pH}=7) ; \mathrm{c}\right)$ $25 \%(\mathrm{~m} / \mathrm{v})$ ferrous ammonium sulfate $+1 \%(\mathrm{v} / \mathrm{v})$ sulfuric acid $+5 \%$ $(\mathrm{m} / \mathrm{v})$ pyrogallic acid; d) air with $\mathrm{NO}_{2}$ passed through iodide solution with no scrubber.
Table 1. Efficiency of oxidant scrubber in retention of $36 \mu \mathrm{g} \mathrm{NO}$ for $30 \mathrm{~min}$. The glass tube was filled with different oxidant scrubber materials of coated supporting material ( $3 \mathrm{~g})$. Scrubber capacity was evaluated by oxidation of iodide solution.

\begin{tabular}{|c|c|}
\hline $\begin{array}{l}\text { Coat Solution } \\
\text { on filter paper }(*)\end{array}$ & $\begin{array}{l}\text { Efficiency of oxidant } \\
\text { scrubber after } \\
30 \text { minutes } \%\end{array}$ \\
\hline $10 \% \mathrm{~K}_{2} \mathrm{CO}_{3}$ & 27 \\
\hline $15 \% \mathrm{~K}_{2} \mathrm{CO}_{3}$ & 50 \\
\hline $25 \% \mathrm{~K}_{2} \mathrm{CO}_{3}$ & 39 \\
\hline $35 \% \mathrm{~K}_{2} \mathrm{CO}_{3}$ & 42 \\
\hline $10 \% \mathrm{~K}_{2} \mathrm{CO}_{3}+10 \%$ glycerol & 86 \\
\hline $15 \% \mathrm{~K}_{2} \mathrm{CO}_{3}+10 \%$ glycerol & 78 \\
\hline $25 \% \mathrm{~K}_{2} \mathrm{CO}_{3}+10 \%$ glycerol & 61 \\
\hline $35 \% \mathrm{~K}_{2} \mathrm{CO}_{3}+10 \%$ glycerol & 69 \\
\hline $10 \% \mathrm{KHCO}_{3}+10 \%$ glycerol & 89 \\
\hline $10 \% \mathrm{KOH}+10 \%$ glycerol & 81 \\
\hline $10 \%$ glycerol & 49 \\
\hline $10 \%$ sulfanilic acid & 64 \\
\hline $10 \%$ sulfanilic acid $+10 \%$ glycerol & 89 \\
\hline $10 \%$ sulfamic acid & 36 \\
\hline $10 \%$ sulfamic acid $+10 \%$ glycerol & 72 \\
\hline $10 \%$ pyridine $+10 \% \mathrm{H}_{2} \mathrm{SO}_{4}+10 \%$ glycerol & 33 \\
\hline $10 \%$ urea $+10 \% \mathrm{H}_{2} \mathrm{SO}_{4}$ & 41 \\
\hline $0,2 \mathrm{M}[\mathrm{Fe}(\mathrm{II}) \mathrm{EDTA}]+5 \%$ pyrogallic acid & $>90$ \\
\hline \multicolumn{2}{|l|}{$25 \%$ ferrous ammonium sulfate $+1 \% \mathrm{H}_{2} \mathrm{SO}_{4}+$} \\
\hline $5 \%$ pyrogallic acid & $>90$ \\
\hline $5 \% \mathrm{KI}+5 \%$ glycerol $(\mathrm{pH}=7)$ & 52 \\
\hline $25 \%$ diethanolamine & 64 \\
\hline $25 \%$ diethanolamine $+10 \%$ glycerol & 68 \\
\hline $25 \%$ triethanolamine & 83 \\
\hline $25 \%$ triethanolamine $+10 \%$ glycerol & 86 \\
\hline
\end{tabular}

(*)concentration of coated solution: $\% \mathrm{~m} / \mathrm{v}$ if solute is solid or $\mathrm{v} / \mathrm{v}$ for liquid

\section{Effects of reduction of the amount of oxidant scrubber material}

In order to design a scrubber that was more compact and easier to handle, the amounts of sorbent materials were reduced and the efficiency of scrubbers re-evaluated. Some sorbent were not tested because their preparation is more laborious. These experiments were carried out using a Teflon tube $(0.3 \mathrm{~cm}$ internal diameter and $7.5 \mathrm{~cm}$ length) fitted with connectors on each end. The packing substrates, about 0.3 $\mathrm{g}$, were held inside the Teflon tube by silanized glass wool. The results showed that the scrubbers maintained a good retention capacity for nitrogen dioxide (Table 2). These scrubbers were then evaluated during collection of DMS onto sampling tubes located downstream of the scrubbers.

\section{Recovery of DMS using different oxidant scrubbers}

It is important that the oxidant scrubbers should neither react with DMS, nor adsorb DMS present in the sample air stream. Tests were conducted to measure possible losses of 
analyte. The DMS standard gas was passed through the oxidant scrubber, and it was collected in the sampling tube over 30 min intervals. Table 3 shows the results of these experiments. The best coating solutions used were: a) $25 \%$ $(\mathrm{m} / \mathrm{v})$ ferrous ammonium sulfate, $1 \%(\mathrm{v} / \mathrm{v})$ sulfuric acid and $5 \%$ pyrogallic acid; b) $25 \%$ triethanolamine. These solutions were also used to coat different supporting materials including: glass wool (fiber medium), silica gel (1-4 mm), and glass pearl (3 mm diameter). Scrubbers containing these materials were tested with the DMS standard gas using the same procedure. Only the solution of $25 \%(\mathrm{~m} / \mathrm{v})$ ferrous ammonium sulfate, $1 \%(\mathrm{v} / \mathrm{v})$ sulfuric acid and $5 \%(\mathrm{v} / \mathrm{v})$ pyrogallic acid coated on glass wool was shown to be inert towards DMS.

Table 2. Efficiency of oxidant scrubber in retention of $36 \mu \mathrm{g} \mathrm{NO}$ using the Teflon tube of $0.3 \mathrm{~cm}$ internal diameter and $7.5 \mathrm{~cm}$ length and with $0,3 \mathrm{~g}$ of coated support material.

\begin{tabular}{lc}
\hline $\begin{array}{l}\text { Coat Solution } \\
\text { on filter paper }(*)\end{array}$ & $\begin{array}{c}\text { Efficiency of oxidant } \\
\text { scrubber \% }\end{array}$ \\
\hline $10 \% \mathrm{~K}_{2} \mathrm{CO}_{3}+10 \%$ glycerol & 52 \\
$10 \%$ sulfanilic acid $+10 \%$ glycerol & 52 \\
$10 \%$ sulfamic acid $+10 \%$ glycerol & 69 \\
$25 \%$ ferrous ammonium sulfate + & \\
$1 \% \mathrm{H}_{2} \mathrm{SO}_{4}+5 \%$ pyrogallic acid & $>90$ \\
$25 \%$ diethanolamine & 64 \\
$25 \%$ triethanolamine & 85 \\
\hline
\end{tabular}

Table 3. Interference of oxidant scrubbers in sampling of DMS. The DMS standard gas solution was passed through each scrubber collected for $30 \mathrm{~min}$ (15.6 $\mu \mathrm{g}$ DMS).

\begin{tabular}{lc}
\hline Scrubber & Relative DMS Recovery \\
& $\%$ \\
\hline $10 \% \mathrm{~K}_{2} \mathrm{CO}_{3}+10 \%$ glycerol & 71 \\
$10 \%$ sulfanilic acid $+10 \%$ glycerol & 76 \\
$10 \%$ sulfamic acid $+10 \%$ glycerol & 71 \\
$25 \%$ ferrous ammonium sulfate + & \\
$1 \% \mathrm{H}_{2} \mathrm{SO}_{4}+5 \%$ pyrogallic acid & 97 \\
$25 \%$ diethanolamine & 82 \\
$25 \%$ triethanolamine & 96 \\
\hline
\end{tabular}

\section{Studies of preservation DMS collected in sampling tube}

The stability of DMS collected as $\left[\mathrm{Pd}(\mathrm{DMS})_{2} \mathrm{Cl}_{2}\right]_{(\mathrm{s})}$ was assessed. DMS $(15.6 \mu \mathrm{g})$ was initially collected in the sampling tube, after which the air/nitrogen dioxide mixture, scrubbed by passage through one of three devices, was passed through the sampling tube for $2 \mathrm{~h}$ (about $144 \mu \mathrm{g} \mathrm{NO} 2$ ). The results show (Table 4) that the scrubbers employed can be used successfully for retention of $\mathrm{NO}_{2}$, and hence preservation of DMS collected. It should be noted that the $\mathrm{NO}_{2}$ concentration used in this experiment was many times higher than typical $\mathrm{NO}_{2}$ concentrations found in the polluted ambient atmosphere.
Table 4. Losses of DMS collected. DMS (15.6 $\mu \mathrm{g})$ was collected on the sorbent, then the scrubbed air $/ \mathrm{NO}_{2}$ mixture was passed through the $\mathrm{Pd}(\mathrm{DMS})_{2} \mathrm{Cl}_{2}$ for $2 \mathrm{~h}\left(14.4 \mathrm{mg} \mathrm{NO} \mathrm{NO}_{2}\right.$.

\begin{tabular}{lc}
\hline $\begin{array}{l}\text { Scrubber Type } \\
\text { (coating solution/substrate) }\end{array}$ & $\begin{array}{c}\text { Relative DMS Recovery } \\
(\%)\end{array}$ \\
\hline $25 \%$ ferrous ammonium sulfate + & \\
$1 \% \mathrm{H}_{2} \mathrm{SO}_{4}+5 \%$ pyrogallic acid & 98 \\
$/$ filter paper & \\
$25 \%$ ferrous ammonium sulfate + & \\
$1 \% \mathrm{H}_{2} \mathrm{SO}_{4}+5 \%$ pyrogallic acid & 97 \\
/ glass wool & 96 \\
$25 \%$ triethanolamine / filter paper & \\
\hline
\end{tabular}

\section{Test of oxidant scrubbers in field sampling}

The analytical method reported here in was used to measure atmospheric DMS levels in the environment. The basic system for sampling comprised an air pump, a gasmeter, a sampling tube (glass wool coated with $\mathrm{Na}_{2} \mathrm{PdCl}_{4}$ ) and a scrubber. A dust filter made from silanized glass wool was placed in front of the filter pack. The oxidant scrubber made from the solution of $25 \%(\mathrm{~m} / \mathrm{v})$ ferrous ammonium sulfate, $1 \%(\mathrm{v} / \mathrm{v})$ sulfuric acid and $5 \%(\mathrm{v} / \mathrm{v}) \mathrm{py}-$ rogallic acid coated on to filter paper was used because it was easier to handle than the other filters. All samples were collected for $3 \mathrm{~h}$ because the levels of DMS were unknown. The sampling was conducted at the Chemistry Institute (Araraquara SP Brasil), July 1995. This site is an urban area and the trace gas compositions may have been affected by the presence of an automobile traffic highway within $500 \mathrm{~m}$, and emissions from anaerobic wastewater treatment $2 \mathrm{Km}$ distant. In the winter (June and July), periodic episodes of odor pollution have been noted at this site. Measurements carried out on polluted days resulted that the level of DMS varied from 3.8-12.4 $\mu \mathrm{g} \mathrm{m}^{3}$. Figure 6 shows the absorption spectra of solutions resulting from field sampling with and without scrubbers. When the scrubber was used, the organic solution obtained from the sampling tube, showed a well-defined absorption peak, with the maximum absorbance at $303 \mathrm{~nm}$ characteristic of unoxidized $\left[\mathrm{Pd}(\mathrm{DMS})_{2} \mathrm{Cl}_{2}\right]$. On the other hand, when the filter pack was removed during sampling, the absorption spectrum of the solution obtained showed the existence of oxidized $\left[\mathrm{Pd}(\mathrm{DMS})_{2} \mathrm{Cl}_{2}\right]$.

\section{Conclusion}

Direct analysis of DMS is generally impossible due to their low concentrations in air, which are frequently below the direct quantification limits of the current methods. Determination of atmospheric DMS employing preconcentration can result in very large sampling losses unless potential oxidants in the air sample are removed prior to the concentration step. Although much work has been done on the analy- 


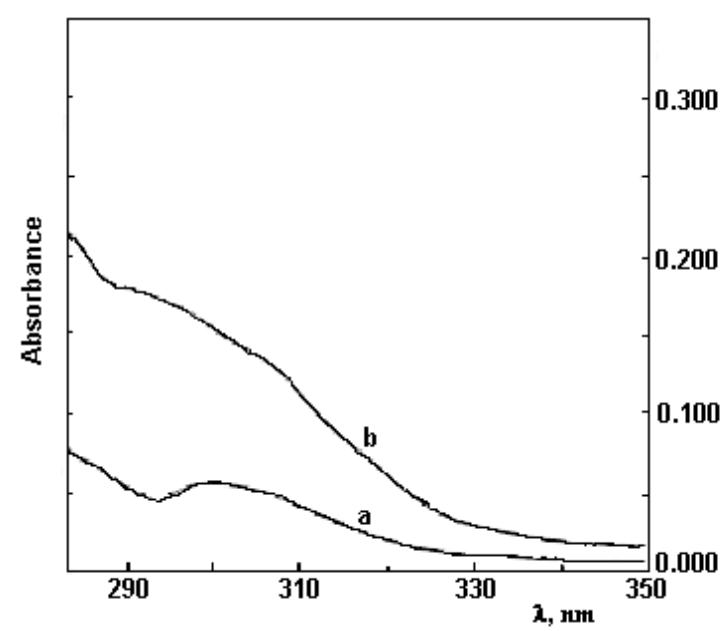

Figure 6. The absorption spectra of solution resulting from field sampling: a) with and b) without scrubber.

sis of DMS in air, the nature of the oxidant interference remains largely unknown. The gas phase reaction of DMS with atmospheric oxidants such as ozone or $\mathrm{NO}_{2}$ is extremely slow 28,29 . In the preconcentration procedure it is possible that the through surface sorption the concentration of both oxidant and sulfur compound are increased such that the reaction proceeds more rapidly than in the gas phase ${ }^{11}$.

Oxidant scrubbers were evaluated for their ability to prevent sampling losses of DMS. The comparison of the filters showed a discrepancy of up to $5 \%$ among replicates. Scrubbers utilizing either (a) a mixture of $25 \%$ ferrous ammonium sulfate, $1 \% \mathrm{H}_{2} \mathrm{SO}_{4}$ and $5 \%$ pyrogallic acid or (b) $25 \%$ triethanolamine possess efficient retention capacity for $\mathrm{NO}_{2}$. The scrubbers are easy to prepare and to store. The results showed that these scrubbers are suitable for the preservation of dimethylsulfide collected during atmospheric sampling. Furthermore, the technique employing such scrubbers, combined with the $\mathrm{Na}_{2} \mathrm{PdCl}_{4}$ sorbent used for preconcentration and analysis of DMS in ambient air, requires minimal sample handling and instrumentation. Results obtained under laboratory conditions and during the course of a small field experiment confirm that the use of a scrubber in combination with a $\mathrm{Na}_{2} \mathrm{PdCl}_{4}$ sorbent is suitable for measurements of DMS. Therefore, the described method offers a useful alternative for the determination of DMS in ambient air. In addition, use of the scrubbers described could probably be adapted to other analytical techniques of precocentration such as cryogenic trapping or adsoption on a solid support.

\section{Acknowledgments}

This work was abstracted from the $\mathrm{PhD}$ thesis submitted by B. A Rodrigues to the Instituto de Química de Araraquara, State University of São Paulo, Brazil (UNESP).
The authors wish to acknowledge the financial support of the Coordenação do Aperfeiçoamento de Pessoal de Nïvel Superior (CAPES) and Conselho Nacional do Desenvolvimento Científico e Tecnológico (CNPq), Brazil.

\section{References}

1. Cullis, C. F.;.Hirschler, M. M. Atmos. Environ. 1980, 14, 1263.

2. Moller, D. Atmos Environ 1984, 18, 29.

3. Kellogg, W. W; Candle, R. D.;.Allen, R. E; Lazrus; A. L; Martel, J. A Science 1972, 175, 587

4. Berresheeim, H. J. Geophys. Res. 1987, 92,13245

5. Cardoso A. A., ; Pitombo, L. R. M. Quím. Nova 1992, 15, 219.

6. Cruse, H; Pomeroy, R. D. J. Amer. Waters Works Assoc. 1969, 61,677

7. Finnerty, W. R. in Bioconversion of Waste Materials to Industrial Product; Martin, A. M. Ed; Elservier New York,1991, p475-500.

8. de Souza, T. L. C. JAPCA 1988, 38, 792

9. Kohl, A.; Riesenfeld, F. Gas Purification; $4^{\text {th }}$ ed. Gulf Publishing Company, Texas, 1985.

10. Taver, G. A.; Dasgupta, P. K. Atmos Environ 1995, 29, 1291

11. Saltzman, E. S.;.Cooper, D. J. In Biogenic Sulfur in the Environment; Saltzman, E.S.; Cooper, D.J. Ed, Washington, ACS symposium serie, 1989, p. 330-335.

12. Hofmann, U.; Hofmann, R; Kesselmeier, J. Atmos Environ 1992, 26, 2445.

13. Davison, B. M; Allen A. G. Atmos Environ 1994, 28, 1721.

14. Kittler, P.; Swan, H.; Ivey, J. Atmos. Environ. 1992, 26, 2661.

15. Wardencki, W. J.Chromatogr.A 1998, 793, 1

16. Braman, R. S.; Ammons, J. M.;Bricker, J. L. Anal. Chem. 1978, 50, 992.

17. Barnard, W. R.; Andreae, M. O.; Watkins, W. E.; Bingemer, H.; Georgii, H. W. J.Geophys. Res. 1982, 87,787 .

18. Andreae, M. O.; Raemdonck, H. Science 1983, $221,744$.

19. Bates, T. S.; Johnson, J. E. EOS 1990, 71, 1254.

20. Saltzman, E.; Copper D.J. Atmos.Chem.1988, 6, 191

21. Cooper, D. J.; Saltzman, E. S. J. Atmos Chem. 1991, $12,153$.

22. Watts, S. F. Environ. Technol. Lett. 1989, 10, 777.

23. Persson, C.; Leck, C. Anal. Chem.1994, 66, 983

24. Pitombo, L. R. M.; Cardoso, A. A. Intern. J. Environ. Anal. Chem. 1994, 54, 221.

25. Cardoso, A. A. Tetracloropaladato (II) de Sódio 
Sobre Sólidos, Sorventes Para Preconcentração de Compostos Reduzidos de Enxofre, Instituto de Química, USP 1991, Ph.D. thesis.

26. Teckentrup, A.; Klockow, D. Anal. Chem.1978, 50, 1728.
27. Littman,F.E.; Benoliel, R.W. Anal.Chem. 1953, 25, 1480.

28. Yin, F.; Grosjean; Seinfeld; J. H. J. Geophys. Res. 1986, 91,14417

29. Grosjean; D. Environ. Sci. Technol. 1984, 18, 460.

Received: August 31, 1999. 